\title{
SURVIVAL AND GROWTH OF SHELTERBELT TREES AT THREE SPACINGS ${ }^{1}$

\author{
W. H. CRAM and G. A. MORGAN ${ }^{2}$
}

William Hugh Cram graduated from the University of Manitoba with a B.S.A. (1939) in Plant Science, an M.Sc. (1948) in Plant Breeding, and from the University of Minnesota a Ph.D. (1951) in Genetics. He was a Field Supervisor for the Forest Nursery Station $(1941-42)$, was overseas with the R.C.A.F. (1942-45), was Plant Breeder (1947-58) and since 1958 has been Superintendent at the Forest Nursery Station, Indian Head, Saskatchewan.

Gordon Allan Morgan was born at Indian Head, Saskatchewan, 1921. He attended the local school, and farmed until 1939. He served with the Canadian Army overseas from 1940 - 45. On his return home he was employed as labourer at the Forest Nursery Station from 1945 - 48. He has been Assistant Technician in Silviculture research 1949 - 59, and in Plant Pathology 1960 - 61.

\section{ABSTRACT}

Seedlings of Caragana arborescens Lam., Acer Negundo L., Ulmus americana $L$., Populus deltoides Bartr. and Fraxinus p. lanceolata Sarg. were planted in 3-row shelterbelts at spacings of 4, 8, and 16 feet at the Forest Nursery Station, Indian Head, Saskatchewan. Data for stand and height are presented after 17 years of growth. Survival of caragana, maple, and ash were not materially influenced by spacing, but that of elm increased from 91 to $100 \%$ and of cottonwood from 0 to $25 \%$, as spacings increased from 4 to 16 feet. Caragana was outstanding with $100 \%$ survival at all spacings. Maximum height of caragana and ash (15 and 19 feet, respectively) was obtained at the 8-foot spacings; while that of maple and elm (23 and 26 feet) was obtained at the 16-foot spacing.

\section{INTRODUCTION}

Several articles have been published on the performance of deciduous tree shelterbelts in the great plains region of the United States, but none is available for the Canadian prairies.

Jensen and Harrington (2) reported in 1930 on the survival and height for 10-year-old shelterbelts at various spacings in Montana. George (1) in 1936 presented the results for a series of 19-year-old shelterbelt tests conducted in North Dakota. In 1946, Munns and Stoeckelar (3) reported on the survival and growth to 1944 of over 1,000 shelterbelts planted from 1936 to 1943 in the Prairie States of the United States.

This paper presents data on tree survival and height in 1959 for shelterbelts containing five deciduous tree species planted at three spacings in 1943 on the Forest Nursery Station, Indian Head, Saskatchewan.

\footnotetext{
${ }^{1}$ Publication No. 13, Forest Nursery Station, Research Branch, Canada Department of Agriculture, Indian Head, Saskatchewan.

'Superintendent and Assistant Technician, respectively.
} 


\section{Materials aND Methods}

The Forest Nursery Station, a unit of the Research Branch of the Canada Department of Agriculture, is located at $50^{\circ} 31^{\prime} \mathrm{N}$., $103^{\circ} 41^{\prime} \mathrm{W}$., with an altitude of 1987 feet, in the South Central Region of the Canadian prairies. In general the climate of the Indian Head area is characterized by a low precipitation and a wide range in temperatures. Climatic data, which was recorded at the Station for the 1943 to 1959 period, has been summarized in Table 1 . Precipitation in the frost-free period at Indian Head ranged from 4.0 inches in 1958 to 19.5 inches in 1954 and averaged 9.4 inches for the 17 -year period

TABLE 1

Precipitation, Temperatures and Frost-free Periods at Indian Head FOR 1943 TO 1959

\begin{tabular}{|c|c|c|c|c|}
\hline \multirow[b]{2}{*}{ Year } & \multirow[b]{2}{*}{ Precipitation $^{1}$} & \multicolumn{2}{|c|}{ Temperatares ${ }^{2}$} & \multirow{2}{*}{$\begin{array}{c}\text { Frost-frec } \\
\text { period }\end{array}$} \\
\hline & & (Max.) & $\overrightarrow{\text { (Min.) }}$ & \\
\hline 1943 & $\begin{array}{c}\text { (inches) } \\
7.3\end{array}$ & $\begin{array}{l}\left({ }^{\circ} \mathbf{F} .\right) \\
95\end{array}$ & $\begin{array}{l}\left({ }^{\circ} \mathrm{F} .\right) \\
-47\end{array}$ & $\begin{array}{c}\text { (days) } \\
94\end{array}$ \\
\hline 1944 & 10.9 & 90 & -33 & 135 \\
\hline 1945 & 5.2 & 100 & -30 & 91 \\
\hline 1946 & 8.4 & 100 & -35 & 74 \\
\hline 1947 & 7.3 & 97 & -43 & 96 \\
\hline 1948 & 7.6 & 91 & -31 & 141 \\
\hline 1949 & 7.5 & 100 & -38 & 112 \\
\hline 1950 & 8.9 & 98 & -42 & 106 \\
\hline 1951 & 10.6 & 96 & -36 & 113 \\
\hline 1952 & 12.8 & 98 & -36 & 125 \\
\hline 1953 & 13.6 & 89 & -32 & 123 \\
\hline 1954 & 19.5 & 89 & -40 & 127 \\
\hline 1955 & 11.3 & 95 & -32 & 125 \\
\hline 1956 & 6.1 & 98 & -30 & 116 \\
\hline 1957 & 7.6 & 98 & -28 & 120 \\
\hline 1958 & 4.0 & 101 & -32 & 103 \\
\hline 1959 & 10.6 & 100 & -34 & 110 \\
\hline$\overline{\text { Means }}$ & 9.4 & 96 & -35 & 112 \\
\hline
\end{tabular}

${ }^{1}$ Precipitation recorded for frost-free period only.

${ }^{2}$ Extreme air temperatures recorded during 12 month period.

${ }^{3}$ Period from day of last spring frost $\left(32^{\circ} \mathrm{F}\right)$ to day of first fall frost.

of this study. Annual temperatures ranged from minus $47^{\circ} \mathrm{F}$ to plus $101^{\circ} \mathrm{F}$., and on the average varied some $131^{\circ}$ in a year. The annual frost-free period ranged from 74 days in 1946 to 141 days in 1948, with an average of 112 days for the 1943 to 1959 period. Soil of the station is classified as an Oxbow boulder-till clay with a $\mathrm{pH}$ of 8.0 . It has a shallow, 4 to 8 inch A-horizon of black clay-loam, a variable 3 to 4 foot clay B-horizon, which blends into the boulder-till clay subsoil at 4 feet.

Three shelterbelts were planted on the Forest Nursery Station in 1943 to investigate the influence of spacing on performance of caragana, (Caragana arborescens Lam.); Manitoba maple, (Acer Negundo L.); white elm, (Ulmus 
americana L.); green ash, (Fraxinus p. lanceolata Sarg.); Eastern cottonwood, (Populus deltoides Bartr.). The age and size of the materials planted are shown in Table 2. All five species were included in each shelterbelt. Each belt was

TABLE 2

Plant Material Used for Establishment of Shelterbelts In 1943

\begin{tabular}{|c|c|c|c|}
\hline \multicolumn{2}{|c|}{ Name of Species } & \multicolumn{2}{|c|}{ Plant Size } \\
\hline Common & Scientific & Age $^{1}$ & Height ${ }^{2}$ \\
\hline Caragana & Caragana arborescens Lam. & $\begin{array}{c}(\mathrm{mo}) \\
15\end{array}$ & $\begin{array}{l}\text { (in.) } \\
18\end{array}$ \\
\hline Manitoba Maple & Acer Negundo $\mathbf{L}$. & 12 & 20 \\
\hline White Elm & Ulmus americana $\mathrm{L}$. & 17 & 20 \\
\hline Eastern Cottonwood & Populus deltoides Bartr. & 16 & 30 \\
\hline Green Ash & $\begin{array}{l}\text { Fraxinus pennsylvanica Marsh. } \\
\text { Var. lanceolata (Berkh.) Sarg. }\end{array}$ & 24 & 22 \\
\hline
\end{tabular}

${ }^{1}$ Months from sowing of seed to lifting of plants.

${ }^{2}$ Average top growth of plants in inches when lifted and planted.

560 feet long and consisted of three rows, which ran from East to West. In all belts the first row was caragana spaced at 12 inches in the row; the second row was alternatively elm, cottonwood, elm and maple; the third row was planted to ash. The distances between rows and between the trees in rows two and three of three belts were 4,8 and 16 feet, respectively. These spacing originally provided each tree with a minimum area of 16 square feet in the first belt, 64 in the second, and 256 square feet in the third belt. The three belts were planted parallel to each other with 16-foot spaces between belts, so that the planting occupied a rectangular area of 120 by 560 feet. As a result the caragana and ash rows had somewhat more space than the maple and elm rows in the 4 and 8 foot spacing belts.

Attempts were made to maintain all belts under clean cultivation, but this was no longer necessary three years after planting for the 4-foot spacings, and seven years after planting for the 8 foot spacings, when the canopy cover gave good weed control within the belts. Owing to the wide spacing of the third belt, the trees have been unable to develop a closed canopy and clean cultivation has been maintained to date.

Survival and height records were compiled in 1959, 17 years after planting, for the three shelterbelts. The number of living trees of each species was recorded for each belt, and the percentage survival or stand computed on the basis of the number of seedlings planted in 1943.

Height of each tree was recorded for each species, except caragana, and the data averaged for each species for each spacing. The height of caragana was recorded for every fourth tree in the 4-foot spacing, every eighth tree in the 8-foot spacing, and every sixteenth tree in the 16-foot spacing. The data for each spacing were averaged.

\section{Results AND Discussions}

The data on survival and growth of the five species of trees grown at three spacings for 17 years are summarized in Tables 3 and 4 . 
TABLE 3

Stand ${ }^{1}$ in 1959 for Five Tree Species Planted in Shelterbelts at Four, Eight and SixteEn Foot SpaCings In 1943

\begin{tabular}{|c|c|c|c|c|c|c|}
\hline \multirow{2}{*}{$\begin{array}{c}\text { Shelterbelt } \\
\text { spacings }\end{array}$} & \multicolumn{5}{|c|}{ Tree Species } & \multirow[b]{2}{*}{ Means } \\
\hline & Caragana & Ash & Elm & Maple & Poplar ${ }^{2}$ & \\
\hline 4 (feet) & $\begin{array}{c}\% \\
-100\end{array}$ & $\%$ & $\%$ & $\begin{array}{l}\% \\
97\end{array}$ & $(\stackrel{\%}{9})$ & 95.7 \\
\hline 8 by 8 & 100 & 100 & 97 & 87 & $(0)$ & 96.1 \\
\hline 16 by 16 & 100 & 100 & 100 & 100 & (25) & 100.0 \\
\hline Averages & 100 & 98 & 96 & 95 & (11) & \\
\hline
\end{tabular}

I Stand as a percentage of trees planted in 1943.

${ }^{3}$ Data for cottonwood listed for comparison-(not included in means).

TABLE 4

Height $^{1}$ in 1959 for Five Tree Species Planted in Shelterbelts at Four, Eight and Sixteen Foot Spacings in 1943

\begin{tabular}{|c|c|c|c|c|c|c|}
\hline \multirow{2}{*}{$\begin{array}{c}\text { Shelterbelt } \\
\text { spacings }\end{array}$} & \multicolumn{5}{|c|}{ Tree Species } & \multirow[b]{2}{*}{ Means } \\
\hline & Caragana & Assh & Maple & Elm & Poplar 2 & \\
\hline 4 by 4 . & $\begin{array}{c}\text { (ft.) } \\
13.0\end{array}$ & $\begin{array}{c}\text { (ft.) } \\
17.0\end{array}$ & $\begin{array}{c}\text { (ft.) } \\
20.6\end{array}$ & $\begin{array}{l}\text { (ft.) } \\
20.0\end{array}$ & $\begin{array}{c}\text { (ft.) } \\
(42.2)\end{array}$ & $\begin{array}{c}\text { (ft.) } \\
17.6\end{array}$ \\
\hline 8 by 8 & -- $15.0^{*}$ & $19.0^{*}$ & 20.1 & $22.7^{*}$ & - & $19.2 *$ \\
\hline 16 by 16 & 15.5 & 19.8 & $23.0^{*}$ & $26.0^{*}$ & $(39.0)$ & $21.1^{*}$ \\
\hline Averages & 14.5 & 18.6 & 21.2 & 22.9 & $(40.6)$ & \\
\hline
\end{tabular}

I Average maximum height of surviving trees in feet.

'Data on cottonwood for comparison only-(not included in means).

* Significantly greater than for preceding spacing.

The data presented in Table 3 show that survival of caragana, maple and ash trees was not materially influenced by planting space. However, survival of cottonwood plantings was increased from 0 to $25 \%$, and of elm from 91 to $100 \%$ as spacings were increased from 4 to 16 feet.

On the other hand, average height for a shelterbelt with caragana, ash, maple and elm was 17 feet at the four-foot spacings, 19 feet at the eight-foot and 21 feet at the 16 -foot spacings. Height of caragana and ash was significantly greater when spacing was increased from 4 feet to 8 feet, but no further improvement resulted when the spacing was increased to 16 feet. The height of maple was greatest at the 16-foot spacing, but showed no appreciable differences between the 4- and 8-foot spacings; whereas the height of elm increased progressively as the spacing was increased from 4 to 8 feet and from 8 to 16 feet.

Caragana was the oustanding species for survival with $100 \%$ stand at all spacings, but achieved a maximum height of only 15 feet after 17 years of growth. Survival of ash was superior on the average to that of both elm and maple, especially at the 8-foot spacing. All species, except cottonwood, demonstrated excellent survival and maximum growth at the 16-foot spacing.

Possibly some of the growth for the outside rows of caragana and ash in the 4- and 8-foot spacing belts could be attributed to availability of additional 
developing area on one side of such trees. Similarly, growth of elm may have been favored over that of maple by the additional area provided through mortality of the cottonwood trees. However, it is suggested that the influence of such additional area would be immaterial since it was limited to only one of the four sides of the trees in each case.

The results of the shelterbelt spacing tests at Indian Head agree generally with those of similar tests reported for the great plains region of the United States. George (1) has presented results for shelterbelt spacing tests conducted in North Dakota from 1915-34 under similar climatic conditions. Best survival and growth of caragana and maple were obtained at a 4-foot by 8-foot spacing, and poplar plantings were eliminated in 16 years regardless of spacing. George concluded that "differences in growth and survival were dependent more on the inherent qualities of the species themselves than on the spacing distance". Jensen and Harrington (2) reported results for 10-year-old shelterbelt plantings at 4, 8 and 16-foot spacings. They found spacing had little influence on survival or growth of green ash, whereas maple benefited with more space. On the basis of their results, Jensen and Harrington questioned the merit of 16-foot spacings between rows and suggested spacings of 4 to 6 feet in the row. From a 1944 survey Munns and Stoeckeler (3) reported maple to show outstanding survival and growth, followed by green ash and elm, whereas caragana had excellent survival but a slow growth rate.

Data on performance from the above studies support the conclusions of Ross (4) that "close planting of 4 by 4 feet gives better results for less labour than the wider spacings". Increased survival and height obtained in the present study by 8 -foot and 16 -foot spacings were economically insignificant when compared with the efficient shelter obtained with a 4-foot spacing which required only one-quarter to one-half the maintenance. Under close spacings of 4 to 8 feet, the trees develop a closed canopy of growth which tends to prevent undergrowths of weeds or grass. On the other hand, at wider spacings of 16 feet the trees failed to produce a closed canopy, so that additional cultivation was required to control weed and grass growth in these shelterbelts. This point is frequently realized by planters who, contrary to recommendations, have planted the rows of their shelterbelt 10 to 20 feet apart for ease of cultivation by farm implements.

\section{REFERENCES}

1. GEORGE, E. J. Growth and Survival of Deciduous trees in Shelterbelt experiments at Mandan, N. Dak. 1915-34. U.S.D.A. Tech. Bull. No. 496. 1936.

2. JENSEN, I. J. and F. M. Harrington. Dry-land shelterbelt tests at the Judith Basin Branch Station. Mont. Agr. Exp. Sta., Bull. 233. 1930.

3. MUNNS, E. N. and J. H. STOECKELAR. How are the great plains shelterbeles? J. For. 44: 237-257, 1946.

4. ROSS, N. M. Success in prairie tree planting. Canada Dept. Interior, Forestry Branch, Bull. 72. 1922. 